\title{
Phosphatase activity in salt-ponds of the Bay of Cádiz
}

\section{Actividad fosfatásica en salinas de la Bahía de Cádiz}

\author{
M.D. Frutos ${ }^{1}$ \\ J. Blasco ${ }^{2 *}$ \\ A. Gómez-Parra ${ }^{1}$ \\ ${ }^{1}$ Departamento de Química-Física \\ Facultad de Ciencias del Mar \\ Universidad de Cádiz \\ Apartado 40 \\ 11510 Puerto Real (Cádiz), Spain \\ ${ }^{2}$ Departamento de Oceanografía \\ Instituto de Ciencias Marinas de Andalucía (CSIC) \\ Campus Univ. Río San Pedro \\ 11510 Puerto Real (Cádiz), Spain \\ * E-mail: julian.blasco@icman.csic.es
}

Recibido en abril de 2003; aceptado en marzo de 2004

\begin{abstract}
Acid and alkaline phosphatase activities (E.C.3.1.3.2 and E.C.3.1.3.1, respectively) were measured in seawater and sediments from different sites of a salt-pond of the Bay of Cádiz. The profiles of enzymatic activity relative to depth were also analysed. Initially, the optimum conditions ( $\mathrm{pH}$, temperature, substrate concentration and amount of sample) for determining enzymatic activities were studied. The apparent activation energies for alkaline phosphatase activity in seawater and sediments were 53.8 and $48.6 \mathrm{~kJ} \mathrm{~mol}^{-1}$, respectively. The $K_{\mathrm{m}}$ and $V_{\max }$ were $10.6 \mathrm{mM}$ and $89 \mu \mathrm{g}$ of 4-nitrophenol $\mathrm{g}^{-1} \mathrm{~h}^{-1}$ and $8.42 \mathrm{mM}^{2}$ $145 \mu \mathrm{g}$ of 4-nitrophenol $\mathrm{L}^{-1} \mathrm{~h}^{-1}$ for sediments and seawater, respectively. Both types of enzymatic activity reached high values in seawater and sediments; in the confined areas of the salt-pond the values were around $100 \mu \mathrm{g}$ of 4 -nitrophenol $\mathrm{L}^{-1} \mathrm{~h}^{-1}$ for seawater and higher for sediments. In general, clear seasonal evolutions for both types of enzymatic activity were found in the seawater, with maxima at the end of summer and minima in winter. No seasonal pattern was evident in the sediment. Stratification of phosphorus regeneration was observed in the sediment column but there was no stratification at depths greater than $15 \mathrm{~cm}$.
\end{abstract}

Key words: phosphatases, seawater, sediment, salt-ponds, Bay of Cádiz.

\section{Resumen}

Se midieron las actividades fosfatásicas ácida y alcalina ((E.C.3.1.3.2 y E.C.3.1.3.1, respectivamente) en muestras de agua y sedimento en diferentes estaciones de salinas de la Bahía de Cádiz. También se analizaron los perfiles de actividad fosfatásica con relación a la profundidad. Se estudiaron las condiciones óptimas $(\mathrm{pH}$, temperatura, concentración de sustrato y cantidad de muestra) para la determinación de las actividades enzimáticas. La energía de activación aparente para la actividad fosfatásica alcalina en agua y sedimento fueron 53.8 y $48.6 \mathrm{~kJ} \mathrm{~mol}^{-1}$, respectivamente. Los valores de $\mathrm{K}_{\mathrm{m}} \mathrm{y} \mathrm{V}_{\max }$ fueron $10.6 \mathrm{mM} \mathrm{y} 89 \mu \mathrm{g}$ de 4-nitrofenol g-1 $\mathrm{h}^{-1}$ y $8.42 \mathrm{mM}$ y $145 \mu \mathrm{g}$ de 4-nitrofenol $\mathrm{L}^{-1} \mathrm{~h}^{-1}$, para sedimentos y agua, respectivamente. Ambos tipos de actividades enzimáticas presentan elevados valores en agua y sedimentos; en las áreas más confinadas de las salinas, los valores alcanzados llegan a ser del orden de $100 \mu \mathrm{g}$ de 4-nitrofenol $\mathrm{L}^{-1} \mathrm{~h}^{-1}$ en las muestras de agua de mar, y superiores en los sedimentos. En general, se apreciaron evoluciones estacionales para ambos tipos de actividades fosfatásicas en las muestras de agua, con máximos a finales del verano y mínimos en invierno. En los sedimentos no se observó esta estacionalidad. La estratificación en la regeneración del fósforo es apreciable en la columna del sedimento, si bien ésta no se observa a profundidades mayores de $15 \mathrm{~cm}$.

Palabras claves: fosfatasas, agua de mar, sedimentos, salinas, Bahía de Cádiz. 


\section{Introduction}

Littoral ecosystems receive large inputs of organic and inorganic materials of lithogenic and anthropogenic origin that tend to accumulate in these areas. Organic matter is the substrate of heterotrophic microbial activities, which results in the release of phosphorus and nitrogen into the environment (Sandstrom, 1982). Nutrient regeneration is the main mechanism of fertilisation in some ecosystems such as the salt marshes around the Bay of Cádiz. These systems are characterised by their high productivity and limited exchange of seawater (Establier et al., 1984).

Potential phosphatase activities are a measurement of the nutritional status of ecosystems (Berman, 1970; Jones, 1972; Perry, 1972; Huber and Kidby, 1984a). The main advantage over other measurement techniques is the large number of samples that can be processed with moderate analytical support. This approach is of special interest in the study of ecosystems with microspatial variations in the physicochemical characteristics of the water column and sediment, for which many sampling stations must be surveyed.

The aim of this study is to determine the potential regeneration rate of inorganic phosphorus and its seasonal and spatial variation in the Bay of Cádiz, differentiating the contribution of each environmental compartment (seawater and surface sediments). Aspects related to the methodology and the optimum conditions $(\mathrm{pH}$, temperature, substrate concentration and amount of sample) for determining the acid and alkaline phosphatases in seawater and sediment were also studied.

\section{Materials and methods}

The salt-pond selected for this study is located in the southern part of the Sancti-Petri Channel, at a distance of $4 \mathrm{~km}$ from the Atlantic Ocean. It has a surface of 30 ha (fig. 1) and three floodgates to control the seawater exchange, allowing water to enter the salt-pond when the height of the tide exceeds $1.5 \mathrm{~m}$. As a consequence of its location, the pond is not greatly affected by urban sewage, and the quality of the water as well as fish productivity are high (Blasco et al., 1987).

For this study of the spatial and seasonal variation of both types of phosphatase activity in seawater and sediment, five sampling stations were selected. Station 1 was situated in the outer part of the salt-pond, and stations 2 to 5 were in the inner area (fig. 2). Station 2 was located in the deeper zone (at $1.5 \mathrm{~m}$ depth), while stations 3,4 and 5 were at sites with a depth of about $0.5 \mathrm{~m}$. At all stations, water samples were collected every 10 days and sediment samples monthly, over a period of 12 months. The samples of seawater were collected with sterilised glass bottles. Immediately after collection, the enzymatic activities were analysed according to the procedure described by Hayashi (1972), with several modifications: volumes of 25 to $150 \mathrm{~mL}$ of water were filtered through a sterile filter of $0.45 \mu \mathrm{m}$ pore size (Millipore HAVPO4700); the filters were then used as inoculate for the culture medium $(5 \mathrm{~mL}$ of $15 \mathrm{mM}$

\section{Introducción}

Los ecosistemas litorales reciben una gran cantidad de entradas de material orgánico e inorgánico de origen litogénico y antropogénico, que tienden a acumularse en ellos. La materia orgánica es el sustrato de la actividad heterotrófica $\mathrm{y}$, como consecuencia de ésta, se liberan nitrógeno y fósforo al medio (Sandstrom, 1982). La regeneración de nutrientes es el mecanismo principal de fertilización en algunos ecosistemas, como es el caso de las marismas de la Bahía de Cádiz. Estos sistemas se caracterizan por su alta productividad y porque su intercambio de agua con el exterior es limitado (Establier et al., 1984).

La medida de las actividades fosfatásicas potenciales ha sido utilizadas como una medida del estado nutricional de los ecosistemas (Berman, 1970; Jones, 1972; Perry, 1972; Huber and Kidby, 1984a). La principal ventaja que representa ésta con respecto a otras técnicas es el elevado número de muestras que pueden ser procesadas con un moderado esfuerzo analítico. Esta aproximación es de especial interés en los ecosistemas con variaciones microespaciales en las características de la columna de agua y el sedimento, en los que es necesario realizar campañas de muestreo con un elevado número de estaciones.

El objeto de este trabajo fue estudiar la velocidad de regeneración potencial del fósforo inorgánico, y su evolución estacional y espacial en las salinas de la Bahía de Cádiz diferenciando la contribución de cada compartimento ambiental (agua y sedimento). También se estudiaron los aspectos relativos a la metodología y las condiciones óptimas $(\mathrm{pH}$, temperatura, concentración de sustrato y cantidad de muestra) para la determinación de las actividades fosfatásicas ácida y alcalina en agua y sedimento.

\section{Materiales y métodos}

La salina seleccionada para este estudio está localizada en la parte sur del caño de Sancti-Petri, a $4 \mathrm{~km}$ del Océano Atlántico. Ésta tiene una superficie de 30 hectáreas (fig. 1), y tres compuertas controlan su intercambio de agua con el exterior, lo que origina que sólo se produzca la entrada de agua en las mareas que tienen una altura mayor de $1.5 \mathrm{~m}$. Como consecuencia de su localización, la calidad de su agua es elevada y también la producción de peces (Blasco et al., 1987).

Para el estudio de la variación estacional y espacial de ambas actividades fosfatásicas en agua y sedimento se seleccionaron cinco estaciones de toma de muestras. La estación 1, se situó en el exterior de la salina, y las estaciones 2 a 5 en la parte interior (fig. 2). La estación 2 se halla localizada en la zona más profunda $(1.5 \mathrm{~m})$, mientras que las estaciones 3,4 y 5 se encuentran en zonas con una profundidad media alrededor de $0.5 \mathrm{~m}$. En todas las estaciones se tomaron muestras de agua cada diez días y, para los sedimentos, esto se hizo mensualmente, durante un periodo de 12 meses. Las muestras de agua fueron recogidas en botellas de vidrio que previamente habían sido esterilizadas. Inmediatamente después de la toma de 


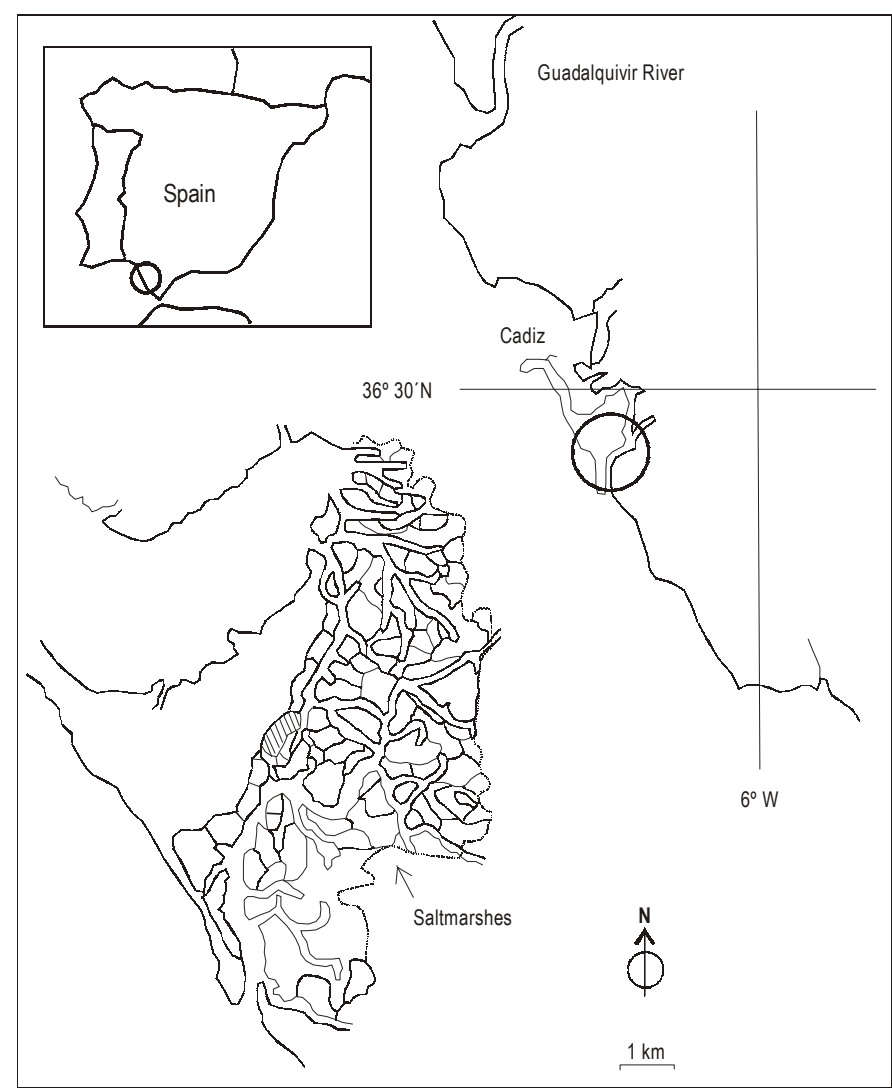

Figure 1. Inner part of the Bay of Cádiz showing the location of the saltpond studied.

Figura 1. Zona interior de la Bahía de Cádiz. Localización de la salina estudiada.

pNPP and $18 \mathrm{~mL}$ of buffer prepared with seawater). To determine the optimum $\mathrm{pH}$ conditions, buffer $0.1 \mathrm{M}$ citric acidsodium citrate, $\mathrm{pH} 3.0-7.0$, and $0.1 \mathrm{M}$ Tris- $\mathrm{HCl}, \mathrm{pH}$ 7.5-10.0, were employed. The effect of substrate concentration on enzymatic activities was analysed in the range of $1-50 \mathrm{mM}$. The incubation time ranged from 12 hours to 8 days, when the effect of incubation time was assayed, and the temperature from $5^{\circ} \mathrm{C}$ to $70^{\circ} \mathrm{C}$. The reaction was stopped by adding $5 \mathrm{~mL}$ of saturated sodium carbonate and $3 \mathrm{~mL}$ of $3 \%$ EDTA. The absorbance was read at $405 \mathrm{~nm}$ (Reichardt et al., 1967) and the results were expressed as $\mu \mathrm{g}$ of 4-nitrophenol released $\mathrm{L}^{-1} \mathrm{~h}^{-1}$. Salinity was measured using a salinometer (Grundy $6230 \mathrm{~N}$ ). Phosphate determination was performed in a Technicon Traacs 800 Autoanalyser. The extraction of pigments and their quantification was carried out with $90 \%$ aqueous acetone, according to the procedure described by Parson et al. (1984).

The sediment samples were collected with a PVC core of $40 \mathrm{~mm}$ inner diameter and were maintained at $-18^{\circ} \mathrm{C}$ until processing. Assays previously carried out showed that freezing did not affect the phosphatase activity of the sediment. When the samples were thawed, slices corresponding to the different depths of the sediment were selected. Sections from the first $3 \mathrm{~cm}$, corresponding to surface sediment at all sites, and sections corresponding to $6-9,12-15,18-21$ and $24-27 \mathrm{~cm}$ depth

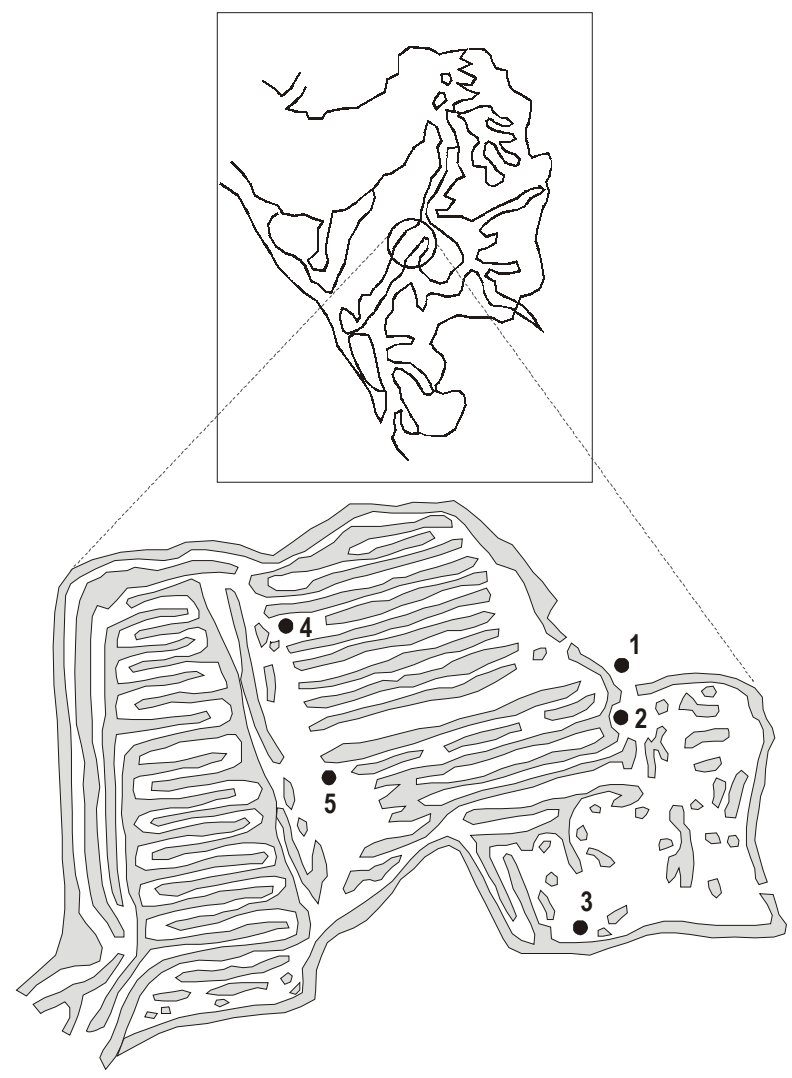

Figure 2. Location of the salt-pond in the salt marshes around the Bay of Cádiz and of the sampling stations in the salt-pond.

Figura 2. Localización de la salina en el área de marismas de la Bahía de Cádiz y de las estaciones de muestreo seleccionadas.

muestra, las actividades enzimáticas se midieron de acuerdo con el procedimiento descrito por Hayashi (1972), con varias modificaciones: se filtraron de $25 \mathrm{a} 150 \mathrm{~mL}$ de muestra a través de filtros estériles de $0.45 \mu \mathrm{m}$ de tamaño de poro (Millipore HAVPO4700). Los filtros fueron empleados como inóculos para el medio de cultivo $(5 \mathrm{~mL}$ de $15 \mathrm{mM}$ pNPP y $18 \mathrm{~mL}$ de tampón preparado en agua de mar). Para determinar las condiciones óptimas de $\mathrm{pH}$, se empleó tampón $0.1 \mathrm{M}$ cítrico-citrato en el intervalo de $\mathrm{pH} 3.0-7.0$ y $0.1 \mathrm{M}$ Tris- $\mathrm{HCl}$ en el intervalo 7.5-10.0. El efecto de la concentración de sustrato sobre ambas actividades enzimáticas se analizó en el intervalo 1-50 mM. Se analizó el efecto del tiempo de incubación entre 12 horas y 8 días, con un intervalo de temperaturas entre 5 y $70^{\circ} \mathrm{C}$. La reacción se finalizó con la adición de $5 \mathrm{~mL}$ de solución saturada de $\mathrm{Na}_{2} \mathrm{CO}_{3}$ y $3 \mathrm{~mL}$ de AEDT al 3\%. La absorbancia se midió a $405 \mathrm{~nm}$ (Reichardt et al., 1967) y los resultados se expresaron como $\mu \mathrm{g}$ de 4-nitrofenol liberado $\mathrm{L}^{-1} \mathrm{~h}^{-1}$. La salinidad se midió con un salinómetro (Grundy 6230N). La determinación de fosfatos se llevó a cabo con un autoanalizador Technicon Traacs 800 . La extracción de pigmentos y su cuantificación fue llevado a cabo con acetona al $90 \%$, de acuerdo con el procedimiento descrito por Parson et al. (1984).

Las muestras de sedimento fueron tomadas con un testigo de PVC de $40 \mathrm{~mm}$ de diámetro interior y se mantuvieron a 
were also taken. These were homogenised by mechanical agitation for $30 \mathrm{~min}$ with $100 \mathrm{~mL}$ of sterile saline solution $\left(36 \mathrm{~g} \mathrm{~L}^{-1}\right)$.

The amount of inoculate employed to determine phosphatase activity was $1 \mathrm{~mL}$ of suspension. Aliquots of $5 \mathrm{~mL}$ of suspension and saline solution, in duplicate, were dried at $80^{\circ} \mathrm{C}$ until constant weight; these were used to determine the amount of dried sediment needed as inoculate. The results are expressed as $\mu \mathrm{g}$ of 4-nitrophenol released $\mathrm{h}^{-1} \mathrm{~g}^{-1}$. The general conditions ( $\mathrm{pH}$, time, temperature and substrate concentration) to determine acid and alkaline phosphatase are reported in table 1.

The Kruskal-Wallis comparison of means test (Ruiz-Maya, 1977) was used for the analysis of the differences between sampling stations and seasons.

\section{Results and discussion}

\section{Analytical conditions}

From a review of the bibliography, the analytical conditions for measuring potential enzymatic activities showed a wide variability depending on the location and sampling season (table 2). This can be due to differences between the species responsible for these activities (phytoplankton and bacterioplankton) and the season when the study was carried out.

The influence on the phosphatase activities of several variables in water and sediment was studied. The variables selected were: $\mathrm{pH}$ of culture medium, inoculate quantity, substrate concentration, temperature and incubation time.

\section{pH of incubation medium}

Figure 3 shows the variation of acid (AcPA) and alkaline (APA) phosphatase activity in terms of $\mathrm{pH}$ for samples from different sites in the Bay of Cádiz in different seasons.

Over the ranges shown, the $\mathrm{pH}$ was tested every 0.5 units. The effect of $\mathrm{pH}$ on phosphatase activity showed considerable variation between the samples, especially for sediment. This is a consequence of the influence of environmental conditions and the diversity of microorganisms and, therefore, of the particular enzymes responsible for phosphatase activities. Similar results have been reported by other authors (Berman, 1970; Huber et al., 1984a). Hayashi (1972) found that, for marine bacteria, maximum phosphatase activity occurred between $\mathrm{pH}$

Table 1. Analytical conditions to determine the AcPA and APA in seawater and sediment samples from the Bay of Cádiz.

Tabla 1. Condiciones analíticas para la determinación de la AcPA y APA en muestras de agua de mar y sedimentos en la Bahía de Cádiz.

\begin{tabular}{ccccc}
\hline $\begin{array}{c}\text { Enzymatic } \\
\text { activity }\end{array}$ & $\mathrm{pH}$ & $\begin{array}{c}\text { Time } \\
(\mathrm{h})\end{array}$ & $\begin{array}{c}\text { Temperature } \\
\left({ }^{\circ} \mathrm{C}\right)\end{array}$ & $\begin{array}{c}\text { Substrate concentration } \\
(\mathrm{mM})\end{array}$ \\
\hline AcPA & 5.5 & 24 & 28 & 15 \\
APA & 8.5 & 24 & 28 & 15 \\
\hline
\end{tabular}

$-18^{\circ} \mathrm{C}$ hasta su procesamiento. Ensayos realizados previamente mostraron que la congelación no afectó la actividad fosfatásica de los sedimentos. Al descongelar las muestras, se seleccionaron una serie de secciones correspondientes a diferentes profundidades del sedimento. La sección de los tres primeros centímetros corresponden a los sedimentos superficiales. Además de ésta, se tomaron muestras correspondientes a los intervalos de 6-9, 12-15, 18-21 y 24-27 cm. Éstas se homogeneizaron por agitación mecánica durante 30 minutos en $100 \mathrm{~mL}$ de una solución salina estéril $\left(36 \mathrm{~g} \mathrm{~L}^{-1}\right)$.

La cantidad de inóculo empleado para la determinación de la actividad fosfatásica fue $1 \mathrm{~mL}$ de suspensión. Se secaron alícuotas de $5 \mathrm{~mL}$ de suspensión y solución salina a $80^{\circ} \mathrm{C}$ hasta peso constante, y éstas se emplearon para determinar la cantidad de sedimento seco utilizado como inóculo. Los resultados se han expresado como $\mu \mathrm{g}$ de 4-nitrofenol liberado $\mathrm{h}^{-1} \mathrm{~g}^{-1}$. En la tabla 1 se muestran las condiciones generales $(\mathrm{pH}$, tiempo, temperatura y concentración de sustrato) para la determinación de las actividades fosfatásicas ácida y alcalina.

El ensayo de comparación de medias de Kruskal-Wallis (Ruiz-Maya, 1977) se empleó para el análisis de las diferencias entre estaciones de muestreo y estacionalidad.

\section{Resultados y discusión}

\section{Condiciones analiticas}

En una revisión de la bibliografía las condiciones analíticas para medir la actividades potenciales mostraron una amplia variabilidad dependiendo de la localización de las estaciones de muestreo (tabla 2). Este hecho puede ser el resultado de las diferencias entre las especies responsables de estas actividades (fitoplancton y bacterioplancton) y el periodo del año en que las muestras fueron recolectadas.

Se analizó la influencia de pH del medio de cultivo, cantidad de inóculo, concentración de sustrato, temperatura y tiempo de incubación, sobre las actividades fosfatásicas en agua y sedimento.

\section{pH del medio de incubación}

La figura 3 muestra la variación de la actividad fosfatásica ácida (AcPA) y alcalina (APA) en función del pH de las muestras procedentes de diferentes estaciones a lo largo del año.

El efecto del $\mathrm{pH}$ sobre la actividad fosfatásica mostró variaciones notables entre muestras, especialmente en el caso de los sedimentos. Este hecho es consecuencia de la influencia de las condiciones ambientales y de la diversidad de los microorganismos, y por tanto de las enzimas específicas responsables de las actividades fosfatásicas. Otros autores (Berman, 1970; Huber et al., 1984a) han obtenido resultados similares. Hayashi (1972) encontró que, para las bacterias marinas, el máximo de actividad fosfatásica se encontró entre pH 5.6 y 9-10. Kuenzler y Perras (1965) encontraron que los máximos de actividad en 16 especies de algas estaban en el intervalo de $\mathrm{pH}$ 4.4-9.8. 
Table 2. Analytical conditions employed to study the potential phosphatase activities.

Tabla 2. Condiciones analíticas empleadas para el estudio de las actividades fosfatásicas.

\begin{tabular}{lccll}
\hline Samples & $\mathrm{pH}$ & $\begin{array}{c}\text { Incubation temperature } \\
\left({ }^{\circ} \mathrm{C}\right)\end{array}$ & Incubation time & References \\
\hline Algal culture & $8.5,9.0$ & $35-37$ & $0.25-2 \mathrm{~h}$ & Fitzgerald and Nelson (1966) \\
Lake water & 8.4 & 25 & $96 \mathrm{~h}$ & Reichardt et al. (1967) \\
Soil & 6.5 & 37 & $60 \mathrm{~min}$ & Tabatabai and Bremner (1969) \\
Lake water & 8.6 & 27 & $96 \mathrm{~h}$ & Berman (1970) \\
Natural water & --- & $15-25$ & $10 \mathrm{~h}$ & Hayashi (1972) \\
Lake water & 7.6 & 15 & $3 \mathrm{days}$ & Jones (1972) \\
Lake water & 8.0 & 20 & $2-4 \mathrm{days}$ & Stevens and Parr (1977) \\
Seawater & 8.5 & $18-23$ & $20-120 \mathrm{~min}$ & Perry (1972) \\
Seawater & 8.2 & 28 & $30 \mathrm{~min}$ & Kobori et al. (1979) \\
Sediment & 8.6 & 37 & $60 \mathrm{~min}$ & Sayler et al. (1979) \\
Seawater & 7.5 & 25 & $24 \mathrm{~h}$ & Huber and Kidby (1984) \\
Sewater & --- & 25 & $24 \mathrm{~h}$ & Degobbis et al. (1986) \\
Lake water & $7.0-9.5$ & 20 & $30-90 \mathrm{~min}$ & Chrost and Overbeck (1987) \\
\hline
\end{tabular}

5.6 and 9-10. Kuenzler and Perras (1965) obtained maximum activity in the range $\mathrm{pH} 4.4-9.8$ for 16 algal species.

Nevertheless, the majority of assays showed the highest values of APA at $\mathrm{pH} 8.5$, while for AcPA this value was between $\mathrm{pH} 5$ and 6 . These optimum $\mathrm{pH}$ levels obtained are similar to those reported by other authors (table 2) as suitable for estimating potential phosphatase activity.

\section{Influence of inoculate quantity and incubation time}

The influence of inoculate quantity and incubation time is shown in figures 4 and 5 . For both variables, linear responses were found for potential phosphatase activity over a wide range of volumes of filtered seawater, sediment and assay times.

With regard to the influence of incubation time on phosphatase activity, a decrease in the rate of substrate degradation was observed from the sixth day of the assay. This is related to the increased concentration of the products released during the reaction (phosphate exerts an inhibition effect on the use of organic phosphorus; Siuda, 1984); 4-nitrophenol, which is very toxic for organisms that synthesize phosphatases, is also increasingly present.

On the other hand, the acclimation period of the organisms to the culture medium is very short. In the case of seawater this is less than one day and for the sediment it is even less, as can be observed in figure 5 .

\section{Influence of incubation temperature}

The effect of incubation temperature was studied in the range of $30-70^{\circ} \mathrm{C}$. The results for water and sediment are
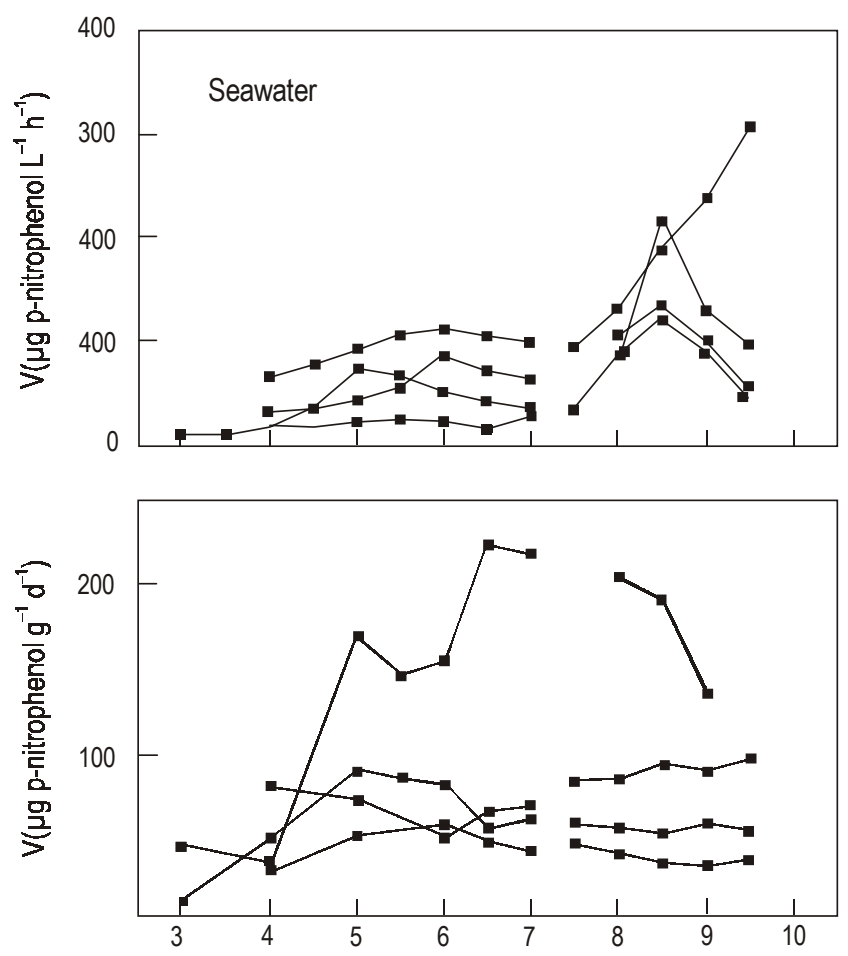

Figure 3. Variation of APA and AcPA in terms of the environmental pH for seawater and sediment samples taken from the salt-pond in different seasons of the year.

Figura 3. Variación de la APA y AcPA en función del pH del medio para muestras de agua de mar y sedimento. 

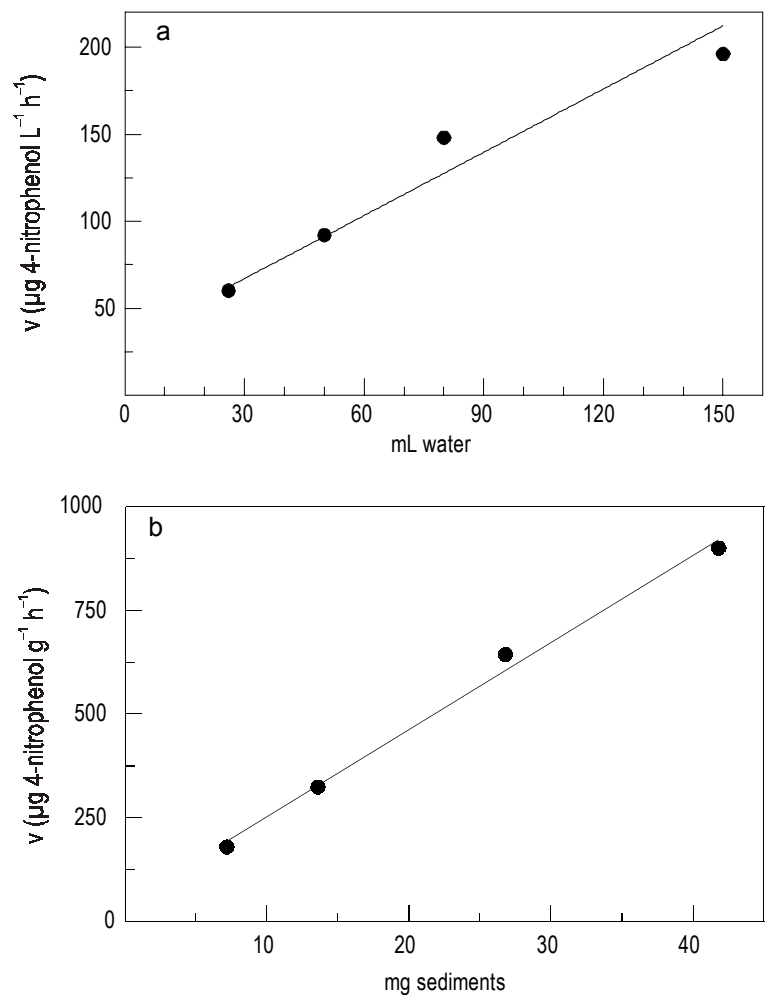

Figure 4. Effect of the amount of inoculate on the APA in (a) seawater and (b) sediment from the salt-pond.

Figura 4. Efecto de la cantidad de inóculo sobre la APA en (a) agua de mar y (b) sedimento.

plotted in figure 6(a, c). An increase in maximum phosphatase activity in seawater was found in the $30-40^{\circ} \mathrm{C}$ range, with enzymatic activity decreasing as the temperature increases beyond this as a consequence of thermal denaturalisation of the enzyme molecules. This effect can be clearly observed when the temperature coefficient $\mathrm{Q}_{10}$ is plotted as bars in the figures.

The mean value of $\mathrm{Q}_{10}$ for the sediments (fig. $6 \mathrm{c}$ ) in the range of $30-60^{\circ} \mathrm{C}$ is 2.01 , while for the water (fig. $6 \mathrm{a}$ ) it is less (1.57). In seawater, the analysed range is $30-50^{\circ} \mathrm{C}$, so when the temperature increases above this level, the activity decreases. These findings suggest that the enzymes involved in phosphatase activity in the sediment are more sensitive to temperature than the seawater enzymes. The values reported for these parameters in sediments were similar to the values found by Frankenberger and Tabatabai (1980) for other soil enzymes (aminohydrolases).

The mean values of apparent activation energy were calculated using the linearized Arrhenius equation (fig. 6b, d). The values obtained for apparent activation energy (Ea) of APA were 53.8 and $48.6 \mathrm{~kJ} \mathrm{~mol}^{-1}$ for seawater and sediment, respectively. These values are similar to the activation energy of benthic fluxes of phosphate measured in situ in the Bay of Cádiz by Forja et al. (1994), who obtained a value of $45.0 \mathrm{~kJ} \mathrm{~mol}^{-1}$.
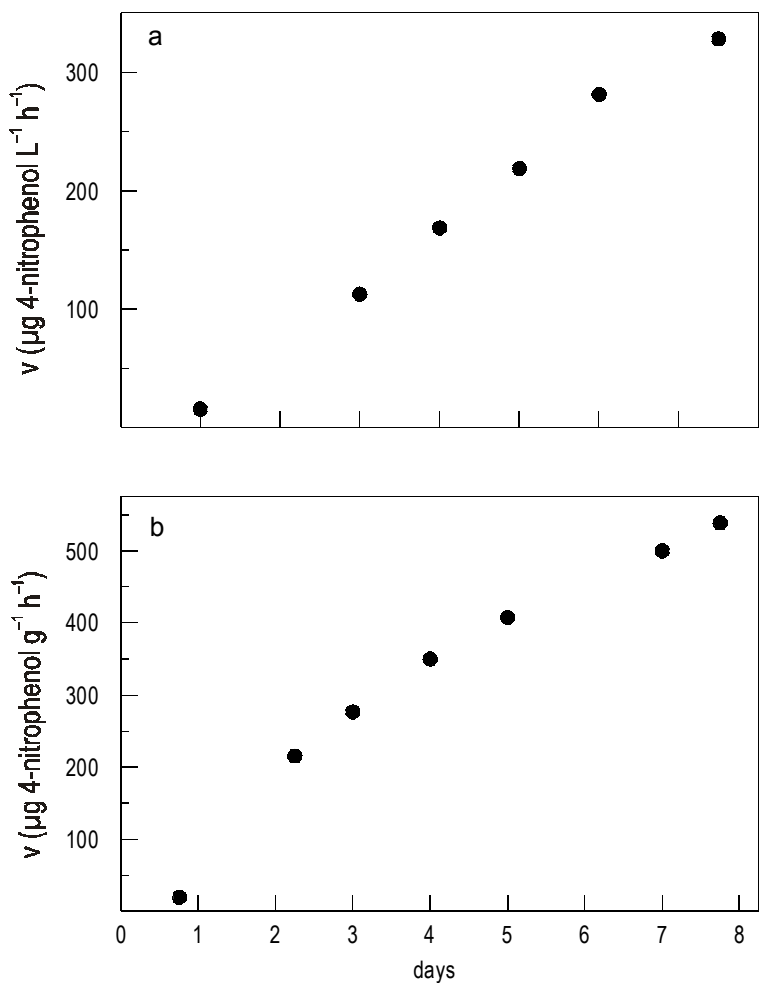

Figure 5. Variation of phosphatase activity with incubation time in (a) seawater and (b) sediment from the salt-pond.

Figura 5. Variación de la actividad fosfatásica con el tiempo de incubación en muestras de (a) agua de mar (b) sedimento.

En nuestro caso, la mayoría de los ensayos mostraron los valores más elevados de APA a pH 8.5, mientras que para la AcPA éstos se encontraron entre $\mathrm{pH} 5$ y 6 . Éstos valores son similares a los encontrados por otros autores (tabla 2), y son adecuados para la medida de la actividad fosfatásica potencial.

\section{Influencia de la cantidad de inóculo y del tiempo de incubación}

La influencia de la cantidad de inóculo y el tiempo de incubación se muestra en las figuras 4 y 5 . Para ambas variables se encontró una respuesta lineal con relación al volumen de agua filtrada, la cantidad de sedimento y el tiempo de ensayo.

Con respecto al efecto del tiempo de incubación sobre la actividad fosfatásica, se observó un descenso en la velocidad de degradación del sustrato a partir del sexto día de ensayo. Esto se relaciona con el incremento de los productos que se liberan durante la reacción (el fosfato ejerce un efecto inhibidor sobre el uso del fósforo orgánico; Siuda, 1984); también se encuentra presente el 4-nitrofenol, que es muy tóxico para los organismos que sintetizan fosfatasas.

Los periodos de aclimatación de los organismos al medio de cultivo son muy cortos: en el caso del agua, es menor a un día, y en el caso de los sedimentos, puede ser incluso más corto, como se aprecia en la figura 5. 

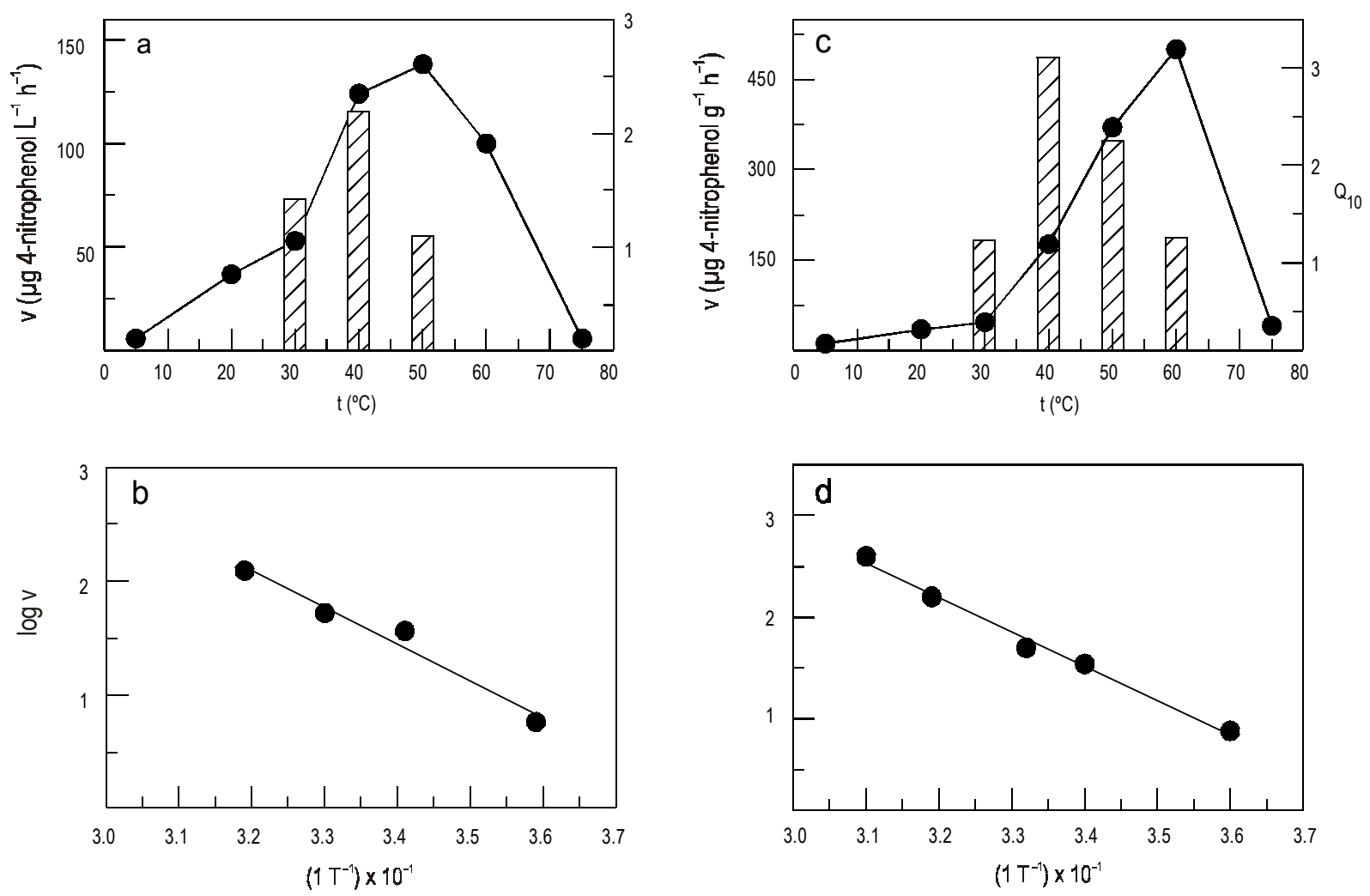

Figure 6. Alkaline phosphatase activity in terms of incubation temperature in (a) seawater and (c) sediment from the salt-pond. Calculation using the Arrhenius equation of the activation energy in (b) seawater and (d) sediment from the salt-pond.

Figura 6. Actividad fosfatásica alcalina en función de la temperatura de incubación en (a) agua de mar y (c) sedimento. Energía de activación, a partir de la ecuación de Arrhenius, en (b) agua de mar y (d) sedimento de la salina.

\section{Influence of substrate concentration}

The kinetic parameters $K_{\mathrm{m}}$ and $V_{\max }$ were determined using the Lineweaver-Burk plot. The agreement between the experimental results and the model can be appreciated in figure 7. The values obtained for $K_{\mathrm{m}}$ and $V_{\max }$ were $10.6 \mathrm{mM}$ and $89 \mu \mathrm{g}$ of 4-nitrophenol $\mathrm{g}^{-1} \mathrm{~h}^{-1}$ and $8.42 \mathrm{mM}$ and $145 \mu \mathrm{g}$ of 4nitrophenol $\mathrm{L}^{-1} \mathrm{~h}^{-1}$ for sediment and seawater, respectively.

On the basis of these two results, the optimum analytical conditions for determining potential phosphatase activities in seawater and sediment in the study area were established. These conditions are summarised in table 1.

The optimum $\mathrm{pH}$ level for potential phosphatase activity varied depending on the sampling station and season. Nevertheless, in order to compare the results, the values selected were $\mathrm{pH} 5.5$ and 8.5 for AcPA and APA, respectively.

The incubation time selected was 24 hours, because no significant increase in the number of microorganisms responsible for phosphatase activity was observed after this period (unpublished data). The incubation of samples with or without sodium azide showed no significant differences $(P<0.05)$. An incubation temperature of $28^{\circ} \mathrm{C}$ was selected as optimum.

\section{Influencia de la temperatura de incubación}

El efecto de la temperatura se estudió en el intervalo 30 $70^{\circ} \mathrm{C}$. En las figuras $6 \mathrm{a} \mathrm{y} 6 \mathrm{c}$ se presentan los resultados para el agua y el sedimento. El máximo incremento de la actividad fosfatásica se encontró en el intervalo $30-40^{\circ} \mathrm{C}$, con un descenso de la actividad por encima de esta temperatura como consecuencia de la desnaturalización térmica de las moléculas de enzimas. Este efecto es evidente cuando se observa el valor de $Q_{10}$, representado en forma de barras en las figuras.

El valor medio de $Q_{10}$ para los sedimentos (fig. 6c) en el intervalo de $30-60^{\circ} \mathrm{C}$ es 2.01 , mientras que en el agua (fig. $6 \mathrm{a}$ ) es menor (1.57). En el caso del agua de mar, el intervalo analizado fue $30-50^{\circ} \mathrm{C}$; cuando la temperatura es superior a este umbral se observa un descenso de la actividad enzimática. Estos resultados sugieren que las enzimas implicadas en la actividad fosfatásica en los sedimentos son más sensibles a la temperatura que las enzimas presentes en el agua de mar. Los valores registrados para estos parámetros en los sedimentos fueron similares a los hallados por Frankenberger y Tabatabai (1980) para otras enzimas del suelo (aminohidrolasas).

Los valores medios de la energía aparente de activación se calcularon mediante el empleo de la ecuación de Arrhenius (figs. $6 \mathrm{~b}$ y $6 \mathrm{~d}$ ). Los valores obtenidos para la energía aparente 

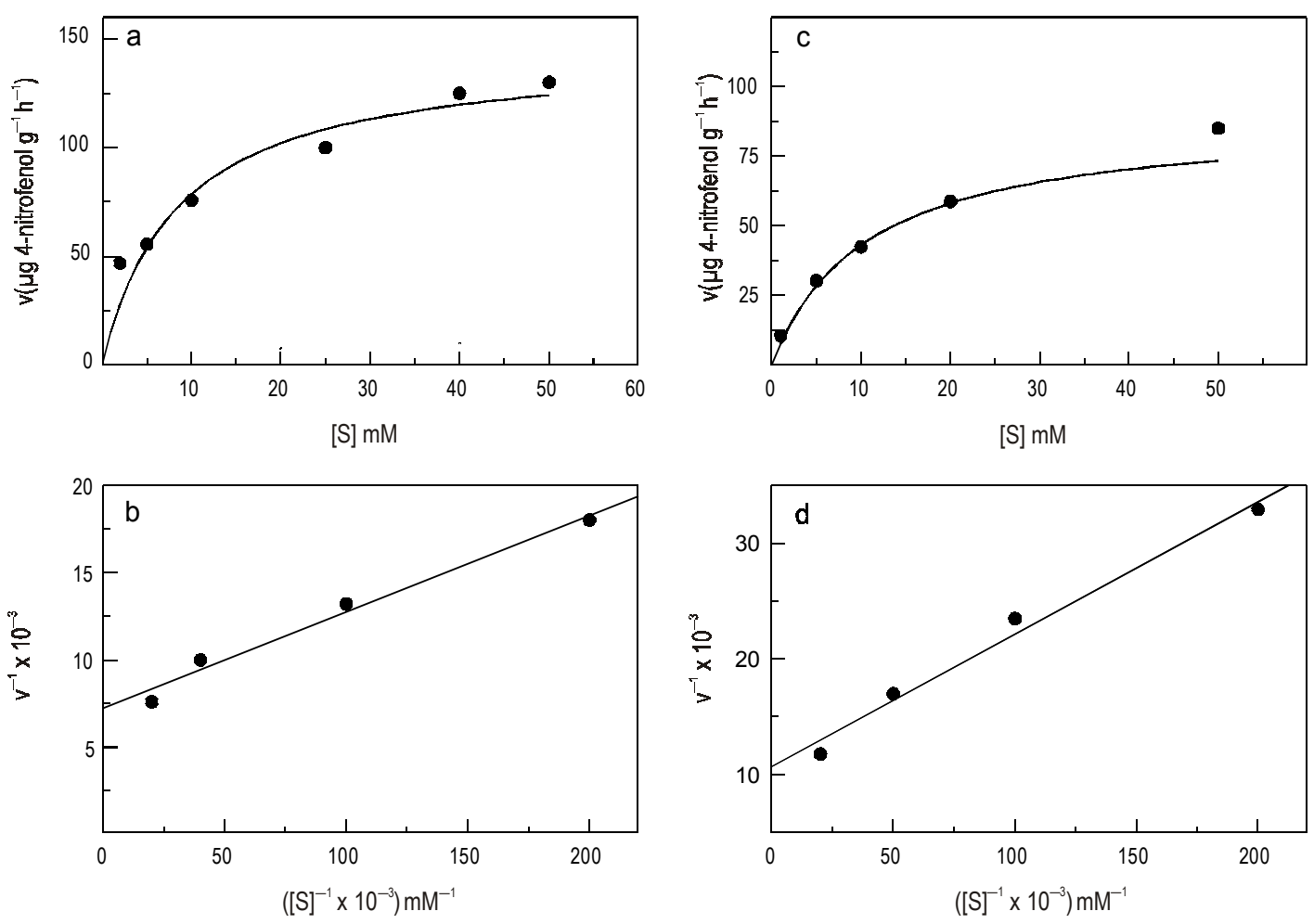

Figure 7. Variation of phosphatase activity relative to substrate concentration in (a) seawater and (c) sediment from the salt-pond. Linear transformation using the Lineweaver-Burk model, in (b) seawater and (d) sediment from the salt-pond.

Figura 7. Variación de la actividad fosfatásica con la concentración de sustrato, en (a) agua de mar y (c) sedimentos. Transformaciones lineales de los resultados mediante el modelo de Lineweaver-Burk en (b) agua de mar y (d) sedimento.

The methodology established allows the quantification of the phosphatase activity derived from the particulate matter of the seawater in the salt-pond. However, the total amount of phosphatase activity in seawater is the sum of the activity from the dissolved fractions and the particulate matter; the proportion varies depending on sample origin and season. In general, phosphatase activity from the particulate matter represents $75-90 \%$ of the total phosphatase activity (unpublished results). A similar range for enzymatic activity associated with particulate matter was reported by Huber and Kidby (1984a) for the Peel Harvey Estuary and by Berman (1970) for Lake Kinneret. Berman et al. (1990) found that a high proportion of phosphatase activities was assigned to the specific size fraction of the natural microplankton $(<0.8 \mu \mathrm{m}>0.2 \mu \mathrm{m})$. Although bacteria and algae are producers of alkaline phosphatase, their relative importance depends on the season and is related to algal blooms (Berman et al., 1990). In the photic zone, the phosphatases are mainly of phytoplanktonic origin. Consequently, there is a high correlation between APA and chlorophyll $a$ in seawater and lakes (Solorzano, 1978; Smith and Kalff, 1981; Stewart and Wetzel, 1982; Siuda, 1984; Huber and Kidby, 1984b). Similarly significant correlations were reported earlier between clorophyll $a$ and APA and AcPA in the ecosystem under study (Frutos, 1996). de activación (Ea) para la APA fueron 53.8 y $48.6 \mathrm{~kJ} \mathrm{~mol}^{-1}$ para agua y sedimento, respectivamente. Estos valores son similares a la energía de activación de los flujos bentónicos de fosfatos medidos in situ en la Bahía de Cádiz por Forja et al. (1994) de $45.0 \mathrm{~kJ} \mathrm{~mol}^{-1}$.

\section{Influencia de la concentración de sustrato}

La determinación de los parámetros cinéticos $\mathrm{K}_{\mathrm{m}} \mathrm{y} \mathrm{V}_{\max }$ fue realizada mediante la ecuación de Lineweaver-Burk. En la figura 7 se aprecia el ajuste entre los resultados experimentales y el modelo. Los valores obtenidos para $\mathrm{K}_{\mathrm{m}} \mathrm{y}_{\max }$ fueron $10.6 \mathrm{mM}$ y $89 \mu \mathrm{g}$ de 4-nitrofenol g-1 $\mathrm{h}^{-1}$ y $8.42 \mathrm{mM}$ y $145 \mu \mathrm{g}$ de 4-nitrofenol $\mathrm{L}^{-1} \mathrm{~h}^{-1}$ para sedimento y agua de mar, respectivamente.

Con base en estos resultados se establecieron las condiciones óptimas para determinar la actividad potencial de las actividades fosfatásicas en agua y sedimento en la zona estudiada, mismas que se encuentran resumidas en la tabla 1.

Los $\mathrm{pH}$ óptimos para la actividad fosfatásica potencial variaron dependiendo de la estación de muestreo y la época del año. No obstante, con el fin de comparar los resultados se seleccionaron los pHs 5.5 y 8.5 para AcPA y APA, respectivamente. 
Spatial and temporal variations of phosphatase activity in the salt-pond

Figure 8 shows the profile of AcPA and APA at two sampling stations in the salt-pond. Station 1 is situated in the outer part of the pond and station 2 in the inner part, a zone with a relatively high degree of confinement. The rest of the sampling stations showed seasonal evolutions similar to that of station 2 . Temperature values ranged from $6.5^{\circ} \mathrm{C}$ to $25^{\circ} \mathrm{C}$ in the summer. Salinity presented values below 40 at station 1 , and between 30 and 50 at station 2 , reaching values close to 80 in the inner part of the salt-pond. The phosphate concentrations were higher in the outer than inner sampling stations. In the first case, values higher than $10 \mu \mathrm{M}$ were observed at the end of autumn, whereas values close to $8 \mu \mathrm{M}$ were observed during the winter at the second station. In general, the lowest values were recorded in the salt-ponds with higher degree of confinement, because the input of $\mathrm{HPO}_{4}{ }^{2-}$ was low, and the limited renovation of water provoked an increase in phytoplankton and macrophyte biomass and in consequence a decrease in nutrient concentrations (Lubián et al., 1985). Chlorophyll $a$ was higher at the inner station than at the outer station; this is because saltponds act as traps for organic matter and the regeneration processes generate increased primary productivity.

The high standard deviations observed are due to the wide variability of the two types of enzymatic activity in the
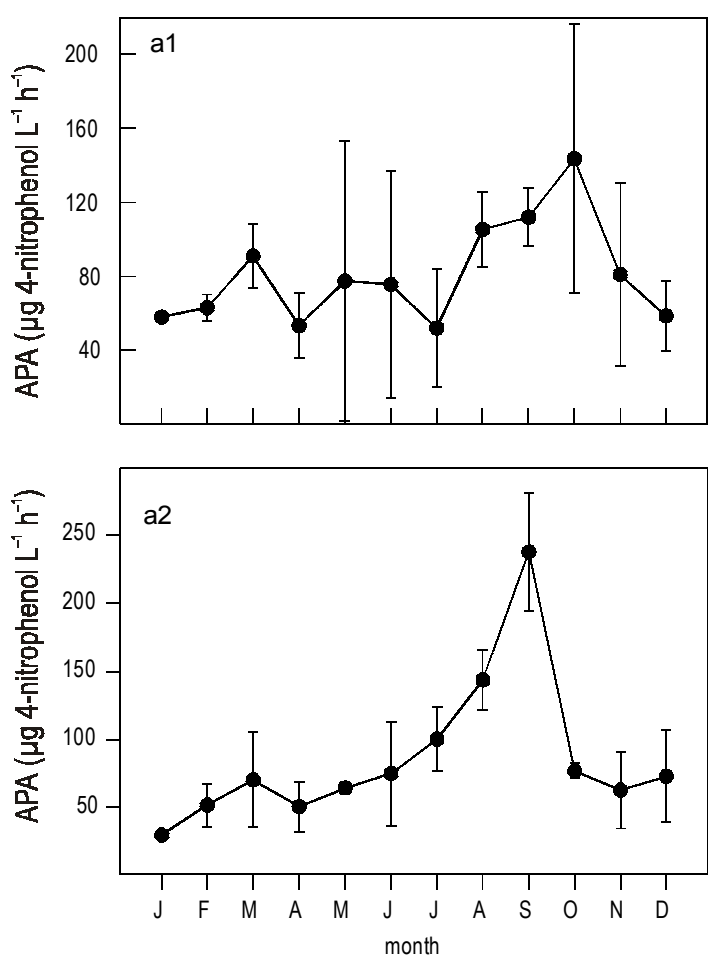

El tiempo de incubación seleccionado fue 24 horas, ya que en este periodo no se produce un incremento significativo del número de organismos responsables de la actividad fosfatásica (datos no publicados). La incubación de las muestras sin o con azida no mostró diferencias significativas $(P<0.05)$. La temperatura de incubación seleccionada fue $28^{\circ} \mathrm{C}$.

La metodología empleada permite la cuantificación de la actividad fosfatásica del material particulado del agua de mar de las salinas. La actividad fosfatásica en el agua es la suma de la actividad en la fracción disuelta y particulada; la proporción varía dependiendo del origen de la muestra y de la estacionalidad. En general, la actividad fosfatásica de la fracción particulada representa entre el 75 y el $90 \%$ de la actividad fosfatásica total (datos no publicados). Datos similares han sido encontrados por Huber y Kidby (1984a) en el estuario Peel, y Harvey y Berman (1970) en el Lago Kinneret. Berman et al. (1990) encontraron que una proporción elevada de las actividades fosfatásicas correspondía a la fracción de tamaño del microplancton natural $(<0.8 \mu \mathrm{m}>0.2 \mu \mathrm{m})$. Aunque las bacterias y las algas son productores de fosfatasa alcalina, su importancia relativa depende de la estación de año, y está relacionada con los blooms algales (Berman et al., 1990). En la zona fótica las fosfatasas son principalmente de origen fitoplanctónico. Consecuentemente, se observa una elevada correlación entre APA y clorofila $a$ en agua de mar y lagos (Solorzano, 1978; Smith y Kalff, 1981; Stewart y Wetzel, 1982; Siuda, 1984; Huber y Kidby, 1984b). Ya anteriormente
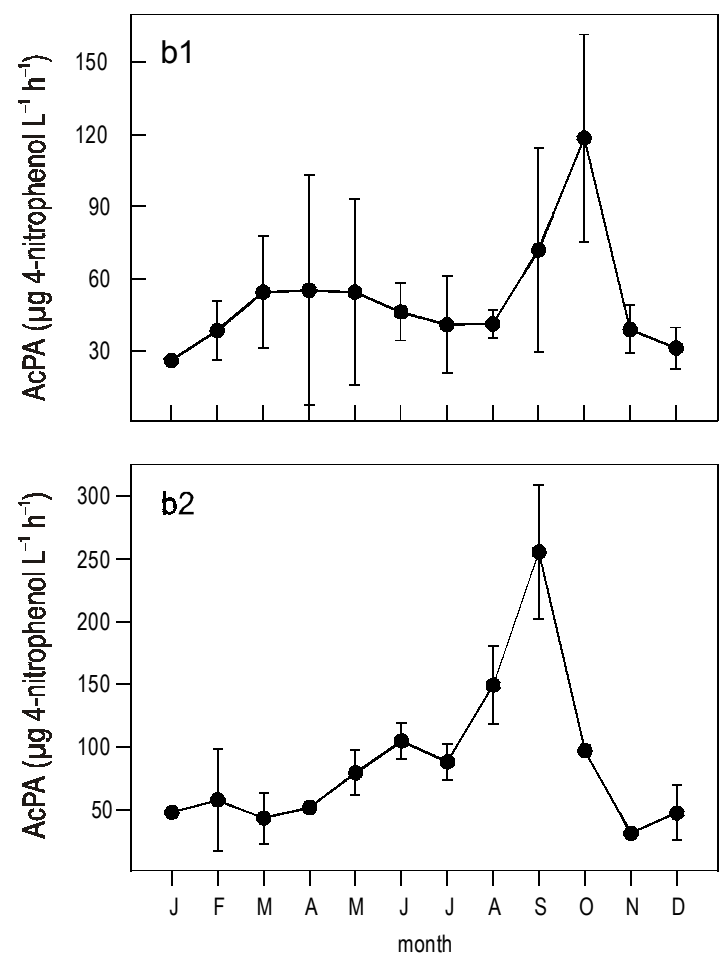

Figure 8. Seasonal evolution of the monthly average values for (a) alkaline and (b) acid potential phosphatase activity in seawater from two points: (1) inside and (2) outside the salt-pond.

Figura 8. Evolución estacional de los valores mensuales promedios para actividades fosfatásicas (a) alcalina y (b) ácida en el agua de mar en dos estaciones de muestreo: (1) interior, y (2) exterior de la salina. 
seasonal samplings made at the same site. Other authors have also observed a similar variability in other littoral zones (Stevens and Parr, 1977; Siuda, 1984).

Temperature and phosphatase activities showed a positive relationship. With regard to phosphate concentration and phosphatase activities, a negative correlation was observed for APA and a positive correlation for AcPA. This behaviour indicates the different biochemical nature of both enzymatic activities.

In general, the phosphatase activity of both types measured in salt-ponds is higher than in other coastal areas. Huber et al. (1985) estimated an average annual value of $45 \mu \mathrm{g}$ of 4-nitrophenol $\mathrm{L}^{-1} \mathrm{~h}^{-1}$ for the Peel and Harvey estuaries (SW Australia), and Taft et al. (1977) reported an average phosphatase activity of about $22 \mu \mathrm{g}$ of 4-nitrophenol $\mathrm{L}^{-1} \mathrm{~h}^{-1}$ for Chesapeake Bay (USA). The values obtained for the Bay of Cádiz were two to three times higher than those observed for these other zones. Nevertheless, the comparison of results obtained with different methods and from different sources must be done cautiously, in part because they represent potential rates. The high potential rate of phosphorus regeneration reported agrees with the benthic flux measured in situ in the Bay of Cádiz by Forja et al. (1994), with an average value of $4.4 \pm 2.5 \mathrm{mmol} \mathrm{m}^{-2} \mathrm{~d}^{-1}$. This value is higher than those found by other authors in littoral areas; e.g., $0.78 \pm 0.05 \mathrm{mmol} \mathrm{m}^{-2} \mathrm{~d}^{-1}$ for the Potomac River estuary (USA) (Callender and Hammond, 1982). This is presumably a consequence of the high inputs of allocthonous organic matter in untreated urban sewage that the Bay of Cádiz receives. These inputs are discharged into an ecosystem with a reduced water volume and where seawater renewal by tidal action is limited (Blasco et al., 1987).

The results obtained and the low values of the nutrient concentrations in the water of salt-ponds (Forja et al., 1990) suggest that in such systems the nutrient regeneration process plays an important role in phytoplankton production. Though there was considerable variability, it can be concluded that there are significant differences $(P<0.01)$ in phosphatase activity among the sampling stations. The highest phosphatase activity was observed in shallow sites and at greater distances from the point where seawater enters the salt-pond, with summer phosphatase levels at stations 2-5 greater than $100 \mu \mathrm{g}$ of 4-nitrophenol $\mathrm{L}^{-1} \mathrm{~h}^{-1}$ during summer, while the annual average for both enzymatic activities is about $75 \mu \mathrm{g}$ of 4-nitrophenol $\mathrm{L}^{-1} \mathrm{~h}^{-1}$. The high values presumably reflect that: (1) the input of phosphorus from outside is reduced and inorganic phosphorus exerts an inhibitory effect on phosphatase activity (Berman, 1970; Stevens and Parr, 1977; Kobori and Taga, 1979; Siuda, 1984; Chrost and Siuda, 1986); (2) in these highly confined areas, an increase in phytoplankton biomass and macrophytes is produced (Lubián et al., 1985), which in turn increases the enzymes in seawater, and these organisms are considered to be mainly responsible for the phosphatase activity in shallow systems (Solorzano, 1978; Smith and Kalff, se han registrado correlaciones significativas entre clorofila $a$ y APA y AcPA en el ecosistema objeto de estudio (Frutos, 1996).

\section{Variaciones espaciales y temporales de la actividad fosfatásica en salinas}

La figura 8 muestra los perfiles de AcPA y APA en dos estaciones de muestreo en la salina. La estación 1 está situada en la parte exterior, y la 2 en el interior con un cierto grado de confinamiento. El resto de las estaciones muestran un comportamiento similar al que exhibe la estación 2. La temperatura varió en el intervalo de 6.5 a $25^{\circ} \mathrm{C}$, alcanzándose esta última temperatura durante el verano; los valores de salinidad en la estación 1 fueron siempre inferiores a 40, mientras que en la estación 2, variaron entre 30 y 50, alcanzándose valores alrededor de 80 en las partes más internas de la salina. La concentración de fosfato en el exterior fue superior que en el interior de la salina; en el primer caso se observaron valores superiores a $10 \mu \mathrm{M}$ a finales de otoño, mientras que durante el invierno en la segunda estación se observaron valores próximos a $8 \mu \mathrm{M}$. En general, los valores más bajos se observaron en las salinas con un mayor grado de confinamiento, debido a que la entrada de $\mathrm{HPO}_{4}{ }^{2-}$ fue baja, y la renovación limitada de agua provocó un incremento de fitoplancton y macrófitos y, en consecuencia, un descenso en la concentración de nutrientes (Lubian et al., 1985). La clorofila $a$ fue superior en las estaciones más internas que en las externas debido a que las salinas actúan como trampas para la materia orgánica, y los procesos de regeneración provocan un incremento de la productividad primaria.

Las elevadas desviaciones estándar que se observan se deben a la amplia variabilidad de los dos tipos de actividad fosfatásica en los muestreos estacionales. Otros autores (Stevens y Parr, 1977; Siuda, 1984) también han encontrado una variabilidad similar.

La temperatura y las actividades fosfatásicas mostraron una relación positiva. Con relación a la concentración de fosfato y actividad fosfatásica, para la APA se observó una correlación negativa, mientras que en el caso de la AcPA ésta fue positiva. Este comportamiento, pone en evidencia la diferente naturaleza de ambas actividades enzimáticas.

En general, la actividad fosfatásica de ambos tipos medidos en las salinas son superiores que los hallados en otras áreas costeras. Así, Huber et al. (1985), en el studio de los estuarios del Peel y Harvey (SO Australia) estimaron un valor medio anual $45 \mu \mathrm{g}$ de 4-nitrofenol $\mathrm{L}^{-1} \mathrm{~h}^{-1}$; Taft et al., (1977) midieron una actividad media anual de $22 \mu \mathrm{g}$ de 4-nitrofenol $\mathrm{L}^{-1} \mathrm{~h}^{-1}$ en la Bahía de Chesapeake (EUA). Los valores obtenidos para la Bahía de Cádiz fueron 2 o 3 veces superiores que los observados para otras zonas. No obstante, la comparación de los resultados obtenidos con diferentes métodos y de distintas fuentes, debe ser llevada a cabo con precaución, ya que se trata de actividades potenciales. La alta velocidad potencial encontrada está concuerda con los flujos bentónicos medidos in situ en la Bahía de Cádiz por Forja et al. (1994), con un valor 
1981; Stewart and Wetzel, 1982; Siuda, 1984; Huber and Kidby, 1984b); and (3) high rates of insolation increase the summer water temperature to $25-40^{\circ} \mathrm{C}$, the optimum range for enzymatic activities.

Moreover, a marked, statistically significant $(P<0.05)$ seasonal evolution was observed in the inner part of the saltpond during the sampling period. At most of the sampling stations in the inner part, the regenerative capacity of phosphorus was found to increase, since the circulation of seawater through the salt-pond is restricted from April to November. In this period, the values of phosphatase activity were 200\% higher than when the circulation of seawater is not restricted. The increase reaches a maximum at the end of summer. Later, a decrease is observed and a minimum is observed in winter.

\section{Potential phosphatase activity in the sediment}

Sediment values are very high. The mean annual value in the salt-pond reached about $240 \mu \mathrm{g}$ of 4-nitrophenol g-1 $\mathrm{h}^{-1}$ and $195 \mu \mathrm{g}$ of 4-nitrophenol $\mathrm{g}^{-1} \mathrm{~h}^{-1}$ for APA and AcPA, respectively. These values are much higher than those found in other studies. For example, Sayler et al. (1979) estimated a mean value of $15 \mu \mathrm{g}$ of 4-nitrophenol $\mathrm{g}^{-1} \mathrm{~h}^{-1}$ for the salt-ponds of Melton Hill in Tennesse, while Degobbis et al. (1986) recorded values of $10 \mu \mathrm{g}$ of 4-nitrophenol $\mathrm{g}^{-1} \mathrm{~h}^{-1}$ for alkaline phosphatase activity in Venice Lagoon.

Sediments are influenced by numerous physical, chemical and biological factors, such as the location of the salt-pond, the degree of water renovation, granulometry and chemical composition of the sediment, and intensity of bioturbation activity. Therefore, it is difficult to establish a clear seasonal evolution. Also, the difficulty of obtaining representative samples is another factor that must be taken into account (Gómez-Parra and Frutos, 1987).

The vertical profiles of both types of enzymatic activity at sampling stations 1 and 4 are shown in figure 9. A similarity in the evolution of AcPA and APA in the sediment column can be observed. This is a consequence of both enzymatic activities having the same origin (Bhatti, 1978).

The evolution of the two types of enzymatic activity in the analysed core is very regular, the highest values being found in the surface sediment; when the depth increases, a decrease in the enzymatic activity is observed and at a depth of $15 \mathrm{~cm}$, values close to zero were measured. Kobori and Taga (1979) found similar variation in the sediments of Tokyo Bay. These profiles are a result of the physicochemical characteristics of the water-sediment interface and the high nutrient fluxes across it (Forja et al., 1994). In consequence, a proliferation of microorganisms responsible for phosphatase activity, principally bacteria, occurs at the surface. In the sediments, the microorganism population diminishes in line with the depth (Krom and Berner, 1981; Degobbis et al., 1986).

It can be concluded that the analytical variables $(\mathrm{pH}$ of incubation medium, inoculate quantity, substrate medio de $4.4 \pm 2.5 \mathrm{mmol} \mathrm{m}^{-2} \mathrm{~d}^{-1}$. Este valor es superior a los hallados por otros autores en áreas litorales, como el estuario del Río Potomac (EUA), donde se encontró un valor de $0.78 \pm$ $0.05 \mathrm{mmol} \mathrm{m}^{-2} \mathrm{~d}^{-1}$ (Callender y Hammond, 1982). Esto es consecuencia, presumiblemente, de las entradas elevadas de materia orgánica alóctona de aguas residuales urbanas no tratadas que recibe la Bahía de Cádiz. Estos aportes son descargados dentro de un ecosistema con un reducido volumen de agua y donde la renovación de sus aguas está limitada por la acción de las mareas (Blasco et al., 1987).

Los resultados hallados y los valores bajos de la concentración de nutrientes en el agua de las salinas (Forja et al., 1990) sugieren que, en estos sistemas, los procesos de regeneración de nutrientes juegan un papel importante en la producción fitoplanctónica. Aunque hay una amplia variabilidad, se puede concluir que hay diferencias $(P<0.01)$ en la actividad fosfatásica entre las estaciones de muestreo. Las actividades fosfatásicas más elevadas se observaron en las zonas más someras y a la distancia mayor de la entrada de agua a la salina, con actividades potenciales en las estaciones 2 a 5 , superiores a $100 \mu \mathrm{g}$ 4-nitrofenol $\mathrm{L}^{-1} \mathrm{~h}^{-1}$ durante el verano, mientras que el promedio anual para ambas actividades es $75 \mu \mathrm{g}$ 4nitrofenol $\mathrm{L}^{-1} \mathrm{~h}^{-1}$. Estos valores elevados reflejan: (1) que la entrada de fósforo desde el exterior es reducida y el fósforo inorgánico ejerce un efecto inhibidor de la actividad fosfatásica (Berman, 1970; Stevens y Parr, 1977; Kobori y Taga, 1979; Siuda, 1984; Chrost y Siuda, 1986); (2) en las áreas altamente confinadas se produce un incremento en la biomasa de fitoplancton y macrófitos (Lubian et al., 1985), lo que origina un incremento de las enzimas en el agua de mar, ya que éstos organismos son los principales responsables de la actividad fosfatásica en ecosistemas someros (Solorzano, 1978; Smith y Kalff, 1981; Stewart y Wetzel, 1982; Siuda, 1984; Huber y Kidby, 1984b); (3) las altas tasas de insolación incrementan la temperatura del agua, llegándose a alcanzar en verano valores de 25 a $40^{\circ} \mathrm{C}$, que se hallan en la zona óptima para estas actividades enzimáticas.

Mas aún, se observó una marcada evolución estacional con diferencias estadísticamente significativas $(P<0.05)$ en la parte interior de las salinas durante el periodo de muestreo. En la mayoría de las estaciones se observó un incremento en la capacidad regenerativa del fósforo, ya que la circulación de agua en el interior de la salina se encuentra restringida de abril a noviembre. En este periodo los valores de actividad fosfatásica fueron un $200 \%$ superiores que cuando la circulación del agua no está restringida. El incremento alcanza un máximo al final del verano, posteriomente se observa un descenso y en invierno se aprecia un mínimo.

\section{Actividades fosfatásicas potenciales en sedimentos}

Los valores de actividades fosfatásicas encontrados en los sedimentos son muy elevados: en las salinas se alcanzan valores de $240 \mu \mathrm{g}$ 4-nitrofenol $\mathrm{g}^{-1} \mathrm{~h}^{-1}$ y $195 \mu \mathrm{g}$ 4-nitrofenol g-1 $\mathrm{h}^{-1}$ para APA y AcPA, respectivamente. Estos valores son mayores 

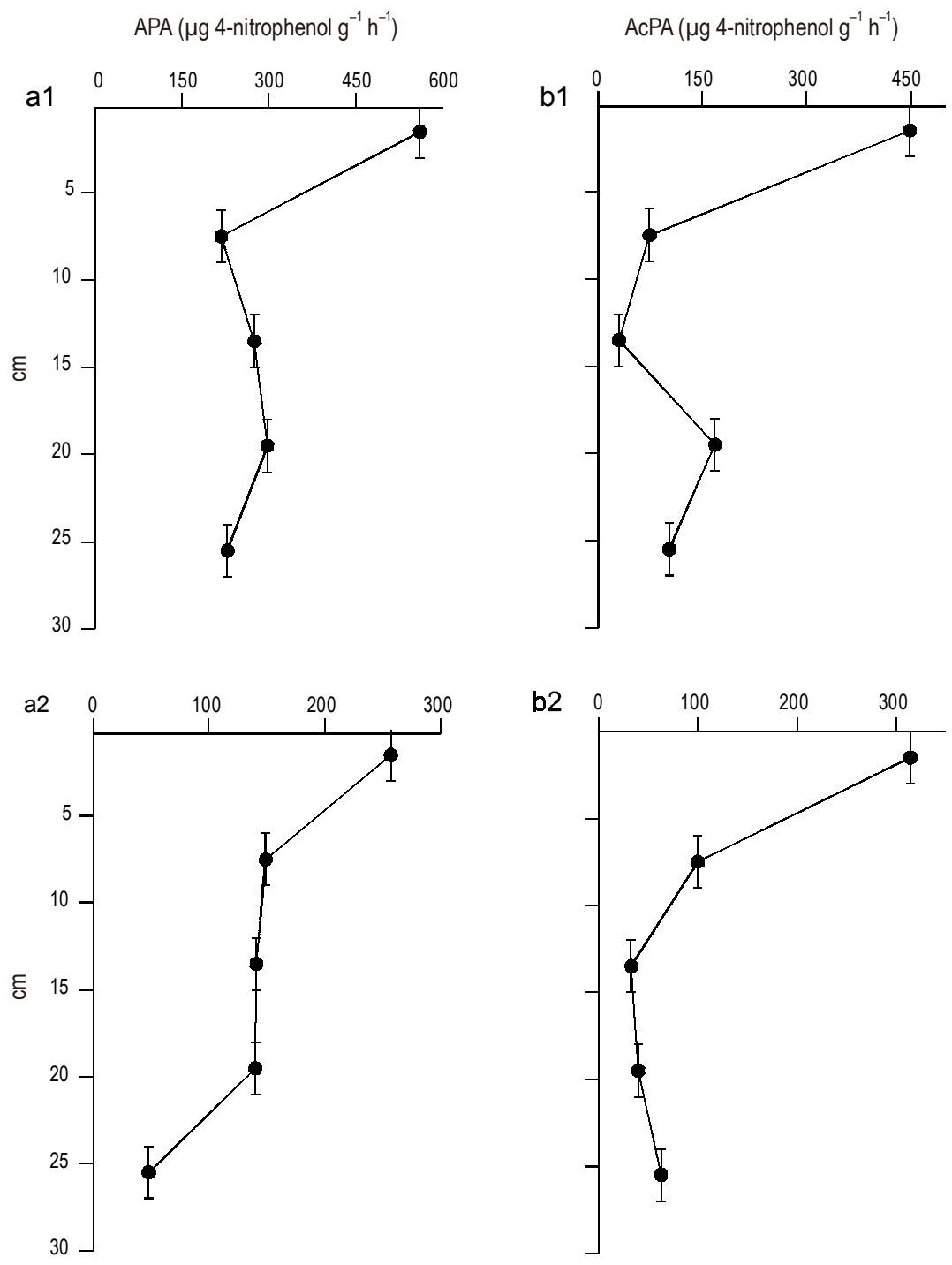

Figure 9. Vertical profiles of the (a) alkaline and (b) acid potential phosphatase activity in sediment from two points: (1) inside and (2) outside the salt-pond.

Figura 9. Perfiles verticiales de la actividad fosfatásica potencial (b) alcalina, y (b) ácida en sedimentos de dos estaciones de muestreo: (1) interior, y (2) exterior de las salina.

concentration, temperature and incubation time) exert a notable influence on the determination of enzymatic activities. The importance of these variables varies among samples depending on their origin and on the season when they were collected.

The average annual values for both types of enzymatic activity (AcPA and APA) were relatively high for both seawater and sediment. This is due to three factors: (1) the high input of allocthonous organic matter in the Bay of Cádiz, which is the substrate for enzymatic activities; (2) the climatic conditions of this area, particularly the high average annual temperatures; and (3) the high degree of confinement of the seawater in salt-ponds. The rate of the mineralization process of inorganic phosphorus shows that the salt-ponds of the Bay of Cádiz are very productive systems, where the regeneration process plays an essential role in supporting the high biomass of the salt-ponds. a los hallados en otros estudios. Así, por ejemplo, Sayler et al. (1979) estimaron un valor medio de $15 \mu \mathrm{g}$ 4-nitrofenol $\mathrm{g}^{-1} \mathrm{~h}^{-1}$ para las salinas de Melton Hill en Tennesse. Degobbis et al. (1986) registraron valores de $10 \mu \mathrm{g}$ 4-nitrofenol $\mathrm{g}^{-1} \mathrm{~h}^{-1}$ para la actividad fosfatásica en la Laguna de Venecia.

Los sedimentos se encuentran sometidos a una gran número de factores físicos, químicos y biológicos, como por ejemplo, la localización de la salina, el grado de renovación del agua, la granulometría y la intensidad de la actividad bioturbadora. Por estas razones, es difícil establecer una clara evolución estacional. La dificultad de obtener muestras representativas es otra factor a tener en cuenta (Gómez-Parra y Frutos, 1987).

En la figura 9 se muestran los perfiles verticales de ambos tipos de actividades enzimáticas en las estaciones 1 y 4 . Se observa una similaridad en la evolución de ambas actividades 


\section{Acknowledgements}

We thank I. Fernández, A. Vidal and P. Vidal for their help in the collection and processing of the samples, and M. Hampel and R. Snart for revision of the English language manuscript.

\section{References}

Bhatti, A.R. (1978). Alkaline phosphatase of Serratia marcescens: Cytochemical localization. Microbios Lett., 4: 83-88.

Berman, T. (1970). Alkaline phosphatases and phosphorus availability in Lake Kinneret. Limnol. Oceanogr., 15: 663-674.

Berman, T., Wynne, D. and Kaplan, B. (1990). Phosphatases revisited: Analysis of particle-associated enzyme activities in aquatic systems. Hydrobiologia, 207: 287-294.

Blasco, J., Gómez-Parra, A., Frutos, M.D. y Establier, R. (1987). Evolución espacial y temporal de la concentración de materia orgánica en los sedimentos de esteros de la bahía de Cádiz. Invest. Pesq., 51: 599-617.

Callender, E. and Hammond, D.E. (1982). Nutrient exchange across the sediment-water interface in the Potomac River estuary. Estuar. Coast. Shelf Sci., 15: 395-413.

Chrost, R.J. and Siuda, W. (1986). A method for determining enzymatically hydrolizable phosphate (EHP) in natural waters. Limnol. Oceanogr., 31: 662-667.

Chrost, R.J. and Overbeck, J. (1987). Kinetics of alkaline phosphatase activity and phosphorus availability for phytoplankton and bacterioplankton in Lake Plubsee (North German eutrophic lake). Microb. Ecol., 13: 229-248.

Degobbis, D., Hommemaluwska, E., Orio, A.A., Donazzolo, R. and Pavoni, B. (1986). The role of alkaline phophatase in the sediments of Venice Lagoon on nutrient regeneration. Estuar. Coast. Shelf Sci., 22: 425-437.

Establier, R., Blasco, J., Gómez-Parra, A. y Escolar, D. (1984). Materia orgánica en los sedimentos de la bahía de Cádiz y sus zonas de marismas y salinas. Invest. Pesq., 48: 285-301.

Fitzgerald, G.P. and Nelson, T.C. (1966). Extractive and enzymatic analyses for the limiting of surplus phosphorus in algae. J. Phycol., 2: 32-37.

Forja, J.M., Gómez-Parra, A. y Blasco, J. (1990). Ritmos circadianos y perfiles verticales en un ecosistema litoral somero. Scient. Mar., 54: 9-18.

Forja, J.M., Blasco, J. and Gómez-Parra, A. (1994). Spatial and seasonal variation of in situ benthic fluxes in the Bay of Cadiz (southwest Spain). Estuar. Coast. Shelf Sci., 39: 127-141.

Frankenberger, W.T. and Tabatabai, M.A. (1980). Amidase activity in soils: Kinetic parameters. Soil Sci. Soc. Am. J., 44: 532-536.

Frutos, M.D. (1996). Actividades fosfatásicas potenciales en aguas y sedimentos de la bahía de Cádiz. Servicio de Publicaciones de la Universidad de Cádiz, 170 pp.

Gómez-Parra, A. y Frutos, M.D. (1987). Representatividad de los valores de materia orgánica en el estudio de sedimentos costeros. Invest. Pesq., 51: 107-120.

Hayashi, L. (1972). Mineralization of organic phosphorus by bacteria in aquatic environments. J. Fac. Fish., 9: 227-250.

Huber, A.L. and Kidby, D.K. (1984a). An examination of the factors involved in determining phosphatase activities in estuarine water. 1. Analytical procedures. Hidrobilogia, 111: 3-11.

Huber, A.L. and Kidby, D.K. (1984b). An examination of the factors involved in determining phosphatase activities in estuarine water. 2: Procedures sampling. Hydrobiologia 111: 13-19. enzimáticas AcPA y APA en la columna del sedimento. Este hecho se debe a que ambas enzimas tienen un origen común (Bhatti, 1978).

La evolución de los dos tipos de actividades enzimáticas en los testigos es muy regular. Los valores más elevados se encuentran en la superficie del sedimento. Cuando se incrementa la profundidad se observa un descenso en la actividad enzimática $\mathrm{y}$, a profundidades mayores de $15 \mathrm{~cm}$ se apreciaron valores próximos a cero. Kobori y Taga (1979) encontraon variaciones similares en los sedimentos de la Bahía de Tokio. Estos perfiles son consecuencia de las características fisicoquímicas de las interfase agua-sedimentos, y de los elevados flujos de nutrientes que se producen a través de ésta. (Forja et al., 1994). En consecuencia, en la superficie se produce una proliferación de organismos responsables de la actividad fosfatásica, principalmente bacterias. En los sedimentos, la población de microorganismos disminuye en línea con la profundidad (Krom and Berner, 1981; Degobbis et al., 1986).

Las variables analíticas, $\mathrm{pH}$ del medio de incubación, cantidad de inóculo, concentración de sustrato, temperatura y tiempo de incubación, ejercen un efecto notable sobre las actividades enzimáticas. La importancia de estas variables varía entre muestras dependiendo de su origen y de la estación del año en que ellas fueron recolectadas.

Los promedios anuales para ambos tipos de actividades enzimáticas (AcPA y APA) fueron relativamente elevados para el agua de mar y el sedimento. Esto es consecuencia de tres factores: (1) la elevada entrada a la Bahía de Cádiz de materia orgánica, que es el sustrato para las actividades enzimáticas; (2) las condiciones climáticas de esta área, especialmente por lo que respecta a las elevadas temperaturas medias anuales; y (3) el alto grado de confinamiento del agua en las salinas. La velocidad del proceso de remineralización del fósforo inorgánico muestra que las salinas de la Bahía de Cádiz son sistemas muy productivos donde los procesos de regeneración tienen un papel esencial en el sustento de la alta biomasa de las salinas.

\section{Agradecimientos}

Deseamos agradecer a I. Fernández, A. Vidal y P. Vidal su ayuda en la recogida y procesamiento de muestras, y a $\mathrm{M}$. Hampel y R. Snart, la revisión del manuscrito en inglés.

Traducido al español por los autores.

Huber, A.L., Gabrielson, J.O. and Kidby, D.K. (1985). Phosphatase activities in the waters of a shallow estuary, western Australia. Estuar. Coast. Shelf Sci., 21: 567-576.

Jones, J.G. (1972). Studies in freshwater microorganisms: Phosphatase activity. J. Ecol., 60: 59-75.

Kobori, H. and Taga, N. (1979). Occurrence and distribution of phosphatase in neritic and oceanic sediments. Deep-Sea Res., 26: 799-808.

Krom, M.D. and Berner, R.A. (1981). The diagenesis of phosphorus in a nearshore marine sediment. Geochim. Cosmochim. Acta, 45: 207-216. 
Kuenzler, E.J. and Perras, J.P. (1965). Phosphatases of marine algae. Biol. Bull. Mar. Biol. Lab. Woods Hole, 128: 271-284.

Lubián, L.M., Establier, R., Yúfera, M. y Fernández-Ales, R. (1985). Estudio del fitoplancton en las salinas de Cádiz dedicadas al cultivo extensivo de peces. Invest. Pesq., 49: 175-218.

Parson, T.R., Maita, Y. and Lalli, M.C. (1984). A Manual of Chemical and Biological Methods for Seawater Analysis. Pergamon Press, Oxford, $173 \mathrm{pp}$.

Perry, M.J. (1972). Alkaline phosphatase activity in subtropical Central North Pacific waters using a sensitive fluorometric method. Mar. Biol., 15: 113-119.

Reichardt, W., Overbeck, J. and Steubing, L. (1967). Free dissolved enzymes in lake waters. Nature, 216: 1345-1347.

Ruiz-Maya, L. (1977). Métodos Estadísticos de Investigación. Presidencia del Gobierno. Instituto Nacional de Estadística, Madrid, $367 \mathrm{pp}$.

Sandstrom, M.W. (1982). Diagenesis of organic phosphorus in marine sediments: Implications for the global carbon and phosphorus cycles. In: J.R. Freney and I.E. Galbally (eds.), Cycling of Carbon, Nitrogen, Sulfur and Phosphorus in terrestrial and aquatic ecosystems. Springer-Verlag, Berlin, pp. 131-141.

Sayler, G.S., Puzzis, M. and Silver, M. (1979). Alkaline phosphatase assay for freshwater sediments: Application to perturbed sediment systems. Appl. Environ. Microbiol., 38: 922-927.
Siuda, W. (1984). Phosphatases and their role in organic phosphorus transformation in natural waters. A review. Pol. Arch. Hydrobiol., 31: 207-233.

Solorzano, L. (1978). Soluble fractions of phosphorus compounds and alkaline phosphatase activity in Loch Crevan and Loch Etive, Scotland. J. Exp. Mar. Biol. Ecol., 34: 227-232.

Smith, R.E.H. and Kalff, J. (1981). The effect of phosphorus limitation on algal growth rates: Evidence from alkaline phosphatase. Can. J. Fish. Aquat. Sci., 38: 1421-1427.

Stevens, R.J. and Parr, M.P. (1977). The significance of alkaline phosphatase activity in Lough Neagh. Freshwat. Biol., 7: 351355.

Stewart, A.J. and Wetzel, R.G. (1982). Phytoplankton contribution to alkaline phosphatase activity. Arch. Hydrobiol., 93: 265-271.

Tabatabai, M.A. and Bremner, J.M. (1969). Use of p-nitrophenyl phosphate for assay of soil phosphatase activity. Soil Biol. Biochem., 1: 301-307.

Taft, J.L., Loftus, M.E. and Taylor, W.R. (1977). Phosphate uptake from phosphomonoesters by phytoplankton in the Chesapeake Bay. Limnol. Oceanogr., 22: 1012-1021. 